\title{
Green Construction Material: Polyethylene Waste Reinforce Concrete for Panel Application
}

\author{
Andrie Harmaji ${ }^{1}$, Siswanti Zuraida ${ }^{2}$ \\ ${ }^{1}$ Department of Metallurgical Engineering, Institut Teknologi dan Sains Bandung, Bekasi, Indonesia \\ ${ }^{2}$ Department of Civil Engineering, InstitutTeknologidanSains Bandung, Bekasi, Indonesia \\ harmaji.a@gmail.com
}

\begin{abstract}
Plastic Composite Panel (PCP) is an innovation in the field of materials that uses recycling plastic waste to construct composite cement panels. This material innovation is one of the solutionto answer environmental problems caused by plastic waste. Some previous studies mostly used plastic waste for concrete aggregates. Thus, making this study different from previous studies. The purpose of this study is to make a prototype of a PCP that is environmentally friendly with panel dimensions sample of $100 \times 30 \times 10 \mathrm{~mm}$ thick. The method used is an experimental test using materials in the form of polyethylene terephtalate (PET) from used water bottle and cement waste as well as testing its physical and mechanical properties carried out in the laboratory. Variations in PET used for testing materials are $0-20 \%$. In addition to mechanical properties, specific gravity and porosity test is carried out. The best results shows that 5\% PET addition to cement paste increase the flexutral strength to $4.47 \mathrm{MPa}$ compared to control sample which has $3.26 \mathrm{MPa}$. Porosity test shows that addition of $10 \%$ PET reduce the density of PCP to $63.64 \%$ compared to control sample that has $44.44 \%$.
\end{abstract}

(C) 2019 IJBESR. All rights reserved.

Keywords: Plastic Composite Panel, Polyethylene Terephthalate, Flexural Strength

\section{Introduction}

Plastics known as synthetic materials produced from synthetic or semi-synthetic organic polymers derived from petro-based chemicals, are able to replace traditional natural polymer materials such as wood, stone ceramics and so on [1]. At present, the plastic industry continues to be very integrated with the oil industry which is developed in parallel, so that it can be considered to be at a high level of interdependence. Mostly accepted that plastic can be considered as a key catalyst for progress with relevant contributions to the development and growth of life [2]. Plastics have become an important asset for humanity which provides economical functions and cannot be easily replaced with other materials. Plastic products have benefited the community in terms of economic activities, employment and quality of life. Most plastics are strong and last for hundreds of years.

Plastic has replaced metals in most components of manufactured goods, including for products such as computers, auto parts and refrigerators, so it often makes products cheaper, lighter, safer, and stronger and also can substitute paper, glass and cardboard in packaging, usually reduces costs and also provides better maintenance than other types of material [3].

Plastics have made a significant contribution in almost every field of human activity today and have greatly helped support human life. Packaging is one of the most important applications of plastic. In fact, around $40 \%$ of 
plastic materials worldwide are used in packaging applications.

Plastics have contributed to creating a hygienic and cost-effective packaging system. The application of plastic materials and derivatives is still growing rapidly due to the low cost and ease of manufacture [4]. Therefore, the amount of high plastic waste accumulates which creates a big challenge for their disposal. Although the use of plastic is needed in many ways, the environment is faced with a serious problem, namely finding an alternative method for removing plastic waste. Disposal of plastic waste in the environment is considered a big problem because of its very low biodegradability and large quantities [5] [6].

In materials engineering, the problem of the existence of plastic has its own challenges. Several studies on materials engineering innovation by recycling plastics have been carried out and have satisfying and applicable results. Several studies have recycled plastic as a mixture of concrete [7] [8] [9] and it was concluded that the utilization of plastic waste as an aggregate substitution of light aggregate in concrete provides a good approach to reduce material costs and solve some of the problems of solid waste generated by plastic.In its development the wall panel component is one of the issues in terms of construction that is effective and efficient which leads to the pre-manufacturing industry.

Research from Bath University has demonstrated that some of the sand used in concrete can be swapped out for plastic waste, to achieve sustainable construction. It was found that PET particles made into size of sand achieve the target compressive strength of $54 \mathrm{MPa}$, similar to structural concrete. Based on several references to recycling plastic waste, the research that will be carried is to recycle used mineral water Polyethylene (PET) bottle waste which will be made into composite cement wall panels or as known as Plastic Component Panel (PCP). Physical and
Mechanical Testing will be carried out such as flexural test and porosity test. This research is important to accommodate the effectiveness of environmentally friendly building methods.

\section{Material and Methods}

Materials used for making PCP is Type-IV Portland Cement/Special Type Cement. PET waste from used plastic bottle were shredded into $10 \mathrm{x} 10 \mathrm{~mm}$ size using shredding device. The variations of PET waste are $0 \%, 5 \%, 10 \%$, $15 \%$, and $20 \%$ [10]. Cement and shredded PET waste mixed with tap-water to form cement paste. After mixed homogenously, the sample was poured into $100 \times 30 \times 10 \mathrm{~mm}$ mould that will be used for mechanical testing. Each variations has three sample each to get accurate data by calculate the average mechanical properties value. Cement paste were allowed to set in the mould for 24 hours, thenit was de-moulded carefully and undergo ambient curing by covering the sample with humid clean clothes and stored it in closed cabinet to ensure normal hydration process is occured.

After 28 days, the sample will undergo porosity test and flexural test. Porosity test was conducted according to ASTM C 642-97 to determine its density and apparent porosity of sample. Flexural test was conducted in Lightweight Structure Laboratory Institut Teknologi Bandung according to ASTM C 78 - 00 to determine its flexural strength using three point bending method. At 28 days, the Three Point Bending test was performed on an Universal Testing Machine with maximum capacity of $10 \mathrm{kN}$. Beam sample were used to test its flexural strength. The flexural strength $(\sigma)$ is calculated as follows :

$$
\sigma=\frac{3 P l}{2 b d^{2}}
$$


Where $\mathrm{P}=$ ultimate load $(\mathrm{N}) ; \mathrm{l}, \mathrm{b}$, and $\mathrm{d}=$ span (90), thickness (30), and height (10) of the beam, respectively ( $\mathrm{mm}$ )

\section{Results and Discussions}

This section will cover about mechanical properties, flexural and compressive strength relationship, and physical properties result and discussions.

\subsection{Mechanical Properties}

The relationship between percentage of used Polyethylene plastic bottle (\%PET) and its Flexural Strength was shown in Figure 1. Results are averages of three specimens.

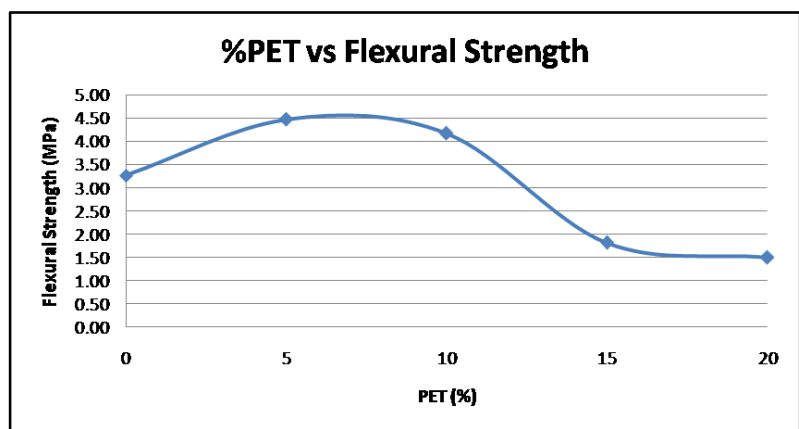

Figure 1: Flexural Strength of PCP reinforced with PET. Cement type was Type-IV Cement. PET amounts were $0-20 \%$ of the cement amount.

Figure 1 shows that addition of 5\% PET will increase the flexural strength of sample, which has 4,47 $\mathrm{MPa}$ from the unreinforced sample which is 3,26 MPa. This value is an acceptable one according to ACI 318 criteria which is 0,3 - 0.6 MPa. Extending the hydration period also resulted in an increase of the flexural strength. Further increase of \% PET addition of $10,15,20 \%$ of $\%$ PET results in slight reduction in flexural strength value, which is 4,17 $\mathrm{MPa}, 1,81 \mathrm{MPa}$, and 1,49 $\mathrm{MPa}$ respectively. Mechanical properties decreases due to lack of adherence at the interface region [11]. This due to the cement that normally will blend with water to make cement paste, affected by PET particles and will make the hydration process slower compared to cement paste without other materials.

\subsection{Flexural Strength and Compressive Strength Relationship}

The relationship of flexural strength and compressive strength has been well researched [12] [13]. ACI Committee 363 (ACI 363R-92) developed the following equation to describe the relationship :

$$
\begin{gathered}
\mathrm{R}=0,94 \sqrt{\mathrm{fc}} \mathrm{MPa} \\
(21 \mathrm{MPa}<\mathrm{fc}<83 \mathrm{MPa}) ; \text { or } \\
\mathrm{R}=11,7 \sqrt{\mathrm{fc}} \mathrm{psi} \\
(3000 \mathrm{psi}<\mathrm{fc}<12000 \mathrm{psi})
\end{gathered}
$$

where $\mathrm{R}=$ Flexural Strength (MPa or psi), and $\mathrm{fc}=$ compressive strength (MPa or psi). Figure 2 shows the compressive strength calculated by above formula.

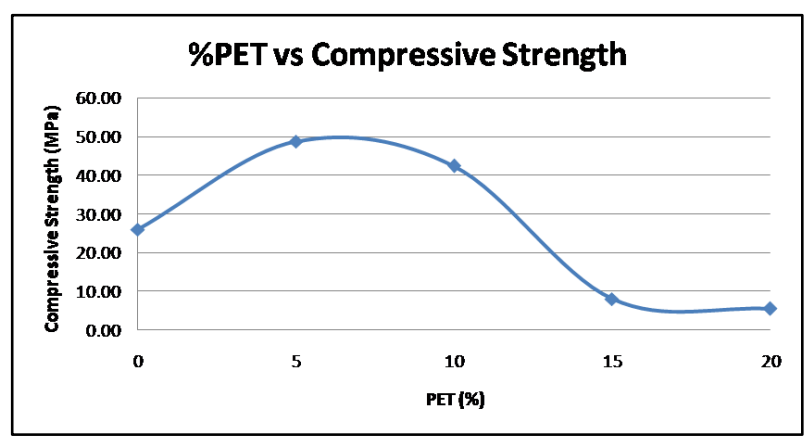

Figure 2: Compressive Strength of PCP reinforced with PET. Cement type was Type-IV Cement. PET amounts were $0-20 \%$ of the cement amount.

Figure 2 shows that addition of 5\% PET will increase the flexural strength of sample from 25,93 $\mathrm{MPa}$ to 48,69MPa. PET addition 10, 15, $20 \%$ of $\%$ PET results in slight reduction in compressive strength value, which is 42,40 $\mathrm{MPa}$, 8,04 $\mathrm{MPa}$, and 5,45 $\mathrm{MPa}$ respectively. This reduction in compressive strength but various research state that it will increase its tensile strength [14] [15].

It means the flexibility will increase, which can be used to withstand the effect of natural disaster such as earthquake application. 


\subsection{Physical Properties}

Figure 3 and 4 shows the relationship of $\%$ PET and Porosity and \%PET and Density, respectively. Porosity of PET reinforced PCP will increased but the Density will decreased gradually. Porosity of PET reinforced PCP values from $44,44-80 \%$, while the Density itself values from 1058,82 - 1185,19 kg/m3 with the addition of $0-20 \%$ used PET water bottle, respectively.

These density value makes all of this sample can be categorized as Light Weight Concrete (LWC), that has a density which varies from $300-1850 \mathrm{~kg} / \mathrm{m} 3$. The relatively low density of LWC makes it has a lower dead load in comparison to other concrete types [16].

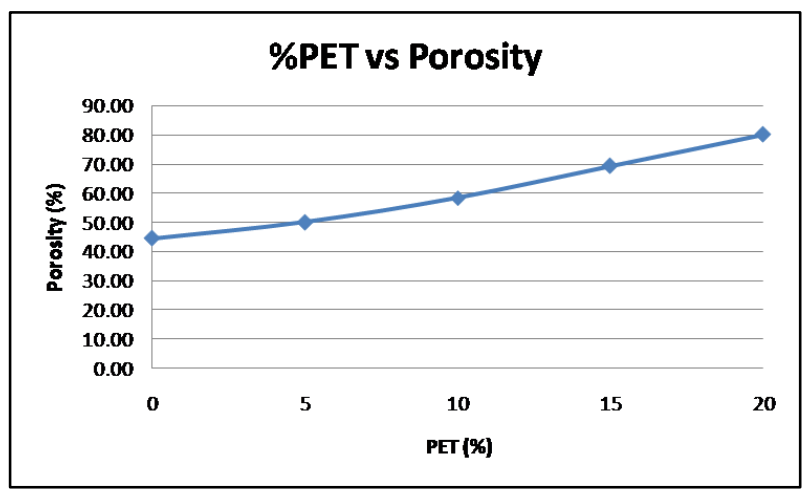

Figure 3: Porosity of PET reinforced PCP. Cement type was Type-IV Cement. PET amounts were $0-20 \%$ of the cement amount.

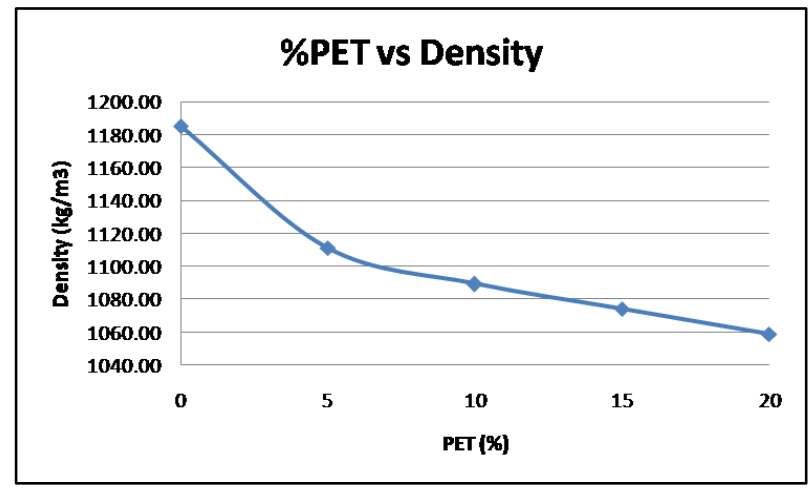

Figure 4: Density of PET reinforced PCP. Cement type was Type-IV Cement. PET amounts were $0-20 \%$ of the cement amount.

\section{Conclusion}

The best flexural strength achieved was 4,47 $\mathrm{MPa}$ at the age of 28 days when used PET water bottle was used. PET percentage was $5 \%$ of the cement content. The compressive strength calculated from flexural strength shows 5\% used Polyethylene Plastic Bottle was equivalent to $48,69 \mathrm{MPa}$, which makes this PCP can be used for wall building.

The apparent porosity and density test categorized all of this sample into Lightweight Concrete categories. Based on mechanical properties, it is concluded that this is potential for green material especially while using as panel application.

\section{Acknowledgement}

We thank Ministry of Research, Technology and Higher Education (Kementerian Riset, Teknologi, dan Pendidikan Tinggi Republik Indonesia) by Penelitian Dosen Pemula (PDP) 2018 research scheme for funding this work.

\section{References}

[1] Groot J., Bing X., Bos-Brouwers H., Bloemhof-Ruwaard J., (2014), A Comprehensive Waste Collection Cost Model Applied To PostConsumer Plastic Packaging. Waste, Resources, Conservation And Recycling, 85, 79-87

[2] Elena - Diana Comăniță1, Raluca Maria Hlihor, Cristina Ghinea, Maria Gavrilescul. (2016). Occurrence Of Plastic Waste In The Environment: Ecological And Health Risks. Environmental Engineering and Management Journal March 2016, Vol.15, No. 3, 675-685

[3] Vipin Koushal, Raman Sharma, Meenakshi Sharma, Ratika Sharma and Vivek Sharma. (2014).

Plastics: Issues Challenges and Remediation. International Journal Waste Resources Volume 4 Issue 1

[4] Ganesh Tapkire, Satish Parihar, Pramod Patil, and Hemraj R. Kumavat (2014), Recycling plastic used in concrete paver block, International journal of research in engineering and technology, Vol. 3, issue 9, 2014, p. 33- 35. 
[5] Baboo Rai, S. Tabin Rushad, Bhavesh Kr, and B. K. Duggal,(2012) Study of waste plastic mix concrete with plasticizer, International scholarly research network, ISRN Civil Engineering, Vol. 1, 2012, p. 1-5.

[6] Pramod Sambhaji Patil, (2015) Behavior of concrete which is partially replaced with waste plastic, International Journal of Innovative Technology and Exploring Engineering IJITEE, Vol. 4, Issue 11, 2015

[7] Subramani, T;.Pugal, V.K. (2015). Experimental Study On Plastic Waste As A Coarse Aggregate For Structural Concrete. International Journal of Application or Innovation in Engineering \& Management (IJAIEM). Volume 4, Issue 5, May

[8] Youcef Ghernouti; Bahia Rabehi; Brahim Safi; Rabah Chaid. (2017). Use Of Recycled Plastic Bag Waste In The Concrete. Journal of International Scientific Publications: Materials, Methods and Technologies Volume 8

[9] Zainab Z. Ismail *, Enas A. AL-Hashmi. (2008). Use Of Waste Plastic In Concrete Mixture As Aggregate Replacement. Waste Management 28, 2041-2047

[10] Asgedom, Abraha Gebrekidan and Desta, Mulu Berhe. The Environmental Impacts Of The Disposal Of Plastic Bags And Water Bottles In Tigray, Northern Ethiopia. Sacha Journal of Environmental Studies. Volume 2 Number 1 (2012) pp. 81-94

[11] Hernandez, Marianella. (2009). Influence of content particle size of waste PET bottles on concrete behavior at different $w / c$ ratio. Waste Management 29(10):2707-16

[12] Behnood, Ali; Verian, Kho; Modiri, Mahsa.(2015). Evaluation of the Splitting Tensile Strength in Plain and Steel FiberReinforced Concrete Based on the Compressive Strength. Construction and Building Materials98:519-529

[13] Barham, Shawn; Darwin, David. (1999).Effects of Aggregate Type, Water-toCementitious Material Ratio, and age on mechanical and fracture properties of concrete. Structural Engineering and Engineering Materials [14] Jibrael MA; Peter F. (2016).Strength and Behavior of Concrete Contains Waste Plastic. J Ecosys Ecograph 6:186.

[15] Sangal, Gopal Swarup. (2018). Study the effect of plastic waste on strength of concrete.
International Journal of Advance Research and Development.

[16] A. A. Okeola; T. I. Sijuade. (2016). Hysteresis Behaviour of Mass Concrete Mixed with Plastic Fibre under Compression. International Journal of Civil and Environmental Engineering Vol. 10, No. 7 
International Journal of Built Environment and Scientific Research Volume 03 Number 01| June2019 p-issn: 2581-1347 | e-issn: 2580-2607 | Pg 1 - 6

(This page is intentionally left blank)

6 | Andrie Harmaji, Siswanti Zuraida 